\title{
The Path Reflection on the Bear Spirit Fulfillment of Modern Youth in China
}

\author{
Jie Yang \\ Chengdu Agricultural College \\ Chengdu, China 611130
}

\begin{abstract}
Chinese contemporary young college students are not only the builders of the socialist cause with Chinese characteristics in the future, but also the backbone of the advanced productive forces of the future. The fulfillment of bear spirit is the spiritual support and work style guarantee of carrying on the history, carrying forward the cause and forging ahead into the future, shouldering the responsibility and successfully carrying out the mission. It is also the spirit regeneration of the contemporary young college students to pursue excellence, be brave to live up to their responsibilities and be good at acting.
\end{abstract}

Keywords-contemporary young college students; the bear spirit; Chinese Dream

\section{INTRODUCTION}

Bear is a kind of tolerance, a quality, a realm, and a responsibility. Whether contemporary young college students can take responsibility, dare to take responsibility, and be good at taking responsibility is the key to whether China can enter the ranks of innovative countries in 2020 and whether it can achieve the goal of "Made in China 2025". As what Chinese President $\mathrm{Xi}$ Jinping mentioned in his speech at the Peking University Teacher-Student Symposium on May 2, 2018:"contemporary youth is a generation that advances with the new era. We are faced with a new era, which is not only the era of the development of the Chinese nation in modern times, but also the most crucial era for the great rejuvenation of the Chinese nation. The vast majority of young people have both broad development space and a great era mission... Young people in the new era should seize the chances of the new era to release the youth dreams in the sky of the motherland. It's honored for them to work hard for the country to build a welloff society and build a socialist modernization power by means of the mission sense as the builders and successors of socialism, and realize the great dream of revival through our struggles".

The fulfillment of the young college students' bear spirit can be said to be the best way to combine the current new economic theory and practice in China. It is an important part of the ideological and political education activities of contemporary young college students, and an effective carrier to improve the social responsibility of contemporary college students. Practicing the bear spirit can not only awaken the sense of responsibility of college students, activate the bear cognition of them, but also enhance their bear ability and shape the personality characteristics of perfection, which will help students to have a clear idea in the mind and act in concert externally, and finally knowledge and action can go hand in hand.

How should contemporary young college students practice the spirit of taking responsibility?

\section{Cultivating One's MORAl Character AND} STRENGTHENING ONE'S CONCENTRATION ABILITY OF "A RELENTLESS GRASP ON THE VERDURED MOUNTAIN-SIDE”

The new situation calls for new demands; the new normal contains new opportunities and new tasks inspire new actions. As the future hope of the motherland and the builders and successors of the cause of socialism with Chinese characteristics, contemporary young college students should do well in self-cultivation and strengthen concentration ability of "a relentless grasp on the verdured mountain-side". The college students should strengthen their ideal and belief, set up a rational consumption view and build up the ideological and moral defense lines to resist corruption and all kinds of temptations by improving their self - cultivation. First of all, it's important to strengthen the inner self - cultivation. Selfcultivation cannot be achieved overnight. Just relying on reading and understanding of relevant books, one cannot become a person of self-cultivation. It is a constant, progressive process. In order to truly adhere to the Communist Party's spiritual home, it is necessary for contemporary college students to have the perseverance of "a relentless grasp on the verdured mountain-side, and the erected root in broken rock". Only by nurturing the Party character and moral character and ration continuously, the real inheritance and highlight of the value pursuit and political character of the Communists can be achieved and the spiritual home of the Communists can be held. The second is to have firm ideals and beliefs. In the face of the increasing renewal of network information technology and the interlaced conflict of multiple values, the contemporary young college students must clear up their own ideals and beliefs, reflect on themselves with the "four whether or not", and know clearly "who I am, for who, where I am in and where to go", and firmly believe in the core values of social socialism. When faced with problems of right or wrong, college students should not be confused. If they encounter interference, they should never be switched. Being carried just along by the tide is not allowed. As President Xi Jinping said: "the ideal belief is the Communist Party's spiritual 'calcium'. If 
there are not ideals and beliefs or the ideals and beliefs are not firm, the spirit will be 'calcium deficiency' and the Party will get 'chondrosis'. The third is to set up a rational consumption view. As a place to study advanced knowledge, the university is no longer an ivory tower away from the secular society. It has moved from the edge of society to the center of society, naturally cannot avoiding the temptation of various "sugarcoated shells" from society. Contemporary young college students should inherit and carry forward the traditional virtues of the Chinese nation' $\mathrm{s}$ arduous struggle, diligence and thrift, and strive to create wealth but not addicted to enjoying it. It's wise to resolutely resist and abandon the wrong consumption concept of excessive fashion consumption such as "to spend tomorrow's money, do today's things". According to the actual situation of their own family, college students should make scientific and rational consumption arrangement on the basis of the order of survival demand, development demand and enjoyment demand, and insist on sustainable consumption, moderate consumption, rational consumption and rational consumption view.

\section{GRASPING THE DETAILS, AND DEVELOPING THE HABIT OF "EXAMINING ONESELF IN THREE WAYS EVERYDAY"}

Habits can both make people and impede people, as American Emerson once said: "Habit is the best servant or the worst master." The main duty of contemporary young college students in the school is to learn scientific and cultural knowledge. In the process of learning scientific and cultural knowledge, it's crucial to develop good behavior habits, which include principles that the things that have been promised must be done, make plan before someone does things, be patient in starting, gradually accelerate in the way of step by step, grasp the details, and develop the habit of "examining oneself in three ways every day." The first is to pay attention to the nuances and grasp the details. In the study and life, contemporary young college students must be a caring person, being careful everywhere and starting from the details. It's right to treat classmates with frankness and look at each other without suspicion. "The self-doubted one does not believe in people, and people are also suspicious about him."It's forbidden to be arrogant and impetuous in learning. The students should be good at learning from excellent classmates around them, constantly overcoming the bad habits of them and developing good study habits. To treat teachers, it's important to fully respect the hard work results of them, evaluate teachers in a reasonable and objective manner, and evaluate them with no blinker, retaliating or even perfunctory attitude. The second is to accumulate for a long time, relying on the accumulation of bits and pieces to develop good habits. "Laozi - Tao Te Ching" says that "a huge tree that fills one's arms grows from a tiny seedling; a nine-storied tower rises from a heap of earth." The formation of good behavior habits of contemporary young college students also needs to accumulate for a long time, so that they can truly turn good behavior habits into behavioral norms, become them into conscious actions, and implement them into all aspects and the whole process of learning and life. For example, ensuring a reasonable supply of nutrients, developing good eating habits; reasonably arranging the schedule of work and rest, and forming a good work and rest system. The third is to be good at reflection and self-discipline. If one doesn't reflect himself, he can't understand the reason. If one doesn't keep selfdiscipline, he can't cultivate himself. It requires a good habit to carry out the spirit of practice, which demands the contemporary young students to become passive, starting from getting up on time every day, to do something that he does not willing to do but is helpful for himself, and to strengthen their behavior habits. For students, they have to behave well in facing the mistakes with a candid mind, being brave in taking responsibility, knowing what is wrong and then, correcting it, but failing to be ashamed of it as well as be sorrowful of it. One should not do evil things though they may be insignificant and should do not give up good things though they may be minor matters. It's better to develop the habit of "examining oneself in three ways everyday".

\section{SEeking Truth and Pragmatism and Holding the ATTITUDE OF "CENTURIES OF WINNING OR LOSING LIES IN REASON"}

China's ancient sages think that the important criterion of "who is a villain and who is a gentleman" lies in that "the great man is not flamboyant, gentlemen are practical". People who are flashy and talkative have always been spurned. Marx once pointed out that people themselves create their own history, but they do not create it as they please, but create it under the established conditions and inheritance from the past. In the final analysis, the process of creating history is the process of starting a business from reality. As contemporary young college students, it's necessary to uphold the attitude of "centuries of winning or losing lies in reason", to adhere to the principle that proceed from reality in everything one does, to respect the law of the development of objective things, and to conscientiously practice the core values of socialism. The first is to meet the actual situation. The contemporary college students should fully integrate their actual situation to arrange their study plan reasonably, find the goal of struggle, set up a correct outlook on life and values, and face themselves and reality in a realistic way. It's forbidden to reach for what is beyond one's grasp and be over crazy about something. It is necessary to correctly deal with the problems of interpersonal communication, school culture and love outlook in real life, and correctly view the periodical and temporary difficulties or obstacles in the advance process, and stick to a rational opinion about the relationship between short-term salary, remuneration, job promotion and long-term career development and career vision. The way of quick success and immediate benefit must be abandoned. The second is to conform to the objective law. At present, China is at the key stage of building a well-off society in an all-round way. The task of reform and development is unprecedentedly arduous and the contradiction is prominent. How to treat contradictions and how to deal with the contradictions has become the most realistic problem for the young college students. This requires dialectical thinking and scientific grasp of the contradiction analysis method to touch the stone to cross the river, break the path dependence bravely, and find the effective way to solve the problem. The third is to conform to the scientific spirit. "The spirit of science is essential to the prosperity, progress and flourishing of a nation." The contemporary college students must cast the scientific attitude of seeking truth and pragmatism, carry 
forward the struggle spirit of independent thinking and innovation, comprehend the basic principles of Marx's philosophy, set up a dialectical materialist world view and improve the scientific quality.

\section{SETTING UP THE SPIRIT OF PIONEERING AND INNOVATION AND THE MIND OF "THE SPIRIT OF THE AGES IS TAKING RESPONSIBILITY"}

If the seedlings are not planted firmly, they will die. If the trees are not planted deeply, they will be dry. At present, China is at a time of storm fortifications in the comprehensive "deep water area" reform. Facing many contradictions, difficulties and challenges, the road of reform has a long way to go, which demands China to advance gradually and entrench itself and overcome difficulties at every step. Entrepreneurship is not only the inevitable requirement of Party style building, but also the realistic demand of deepening reform. As a contemporary young college student, the first thing is to set up a correct view of employment. Influenced by the traditional concept of "one makes farming or leaning, for which the purpose is not food and salary." and "officialdom is the natural outlet for good scholars," some students look at an official career as a very noble profession, and those technical and service jobs are seen as low and humble ones. This has led to discrimination against vocational and technical education with promising prospects. There is no distinction between lowliness and nobleness for occupation and one may distinguish himself in any trade. As Zhang Lei, a Northern Song Dynasty writer, said: "the trades never be differentiated by nobleness and lowliness, how can a man be in pursuit of leisure?"There is no distinction between noble and low work, but just different ambitions. The second is the burden. The spirit of taking responsibility is an important part of the comprehensive quality of college students, and it is also the only way for the all-round development and success of university students. Especially in the process of promoting the historical development of "China dream", it is inevitably to encounter some difficulties and obstacles. Therefore, contemporary young college students should have the burden spirit of "knowing the difficulties and making progress" and "marching forward courageously". At the same time, it is important to have an international vision to look at the world, face the future, and use new thinking, new ideas, new methods to see and understand the bear spirit practice of contemporary college students. Then, it's necessary to do a good job. The socalled "doing a good job" means that students should do work in a steadfast way and can make full use of both hands and brain. Moreover, they shall not be eloquent and showy but no practical martial arts. From the current employment situation in China, what is missing is not posts, but a high-end, technical and compound practical talent who can do both mental work and physical work. People who use their brains can't do things, and people who do things will not use their brains. Mental labor cannot do physical labor, physical labor cannot do mental work. And this is a true portrayal of the contemporary young college students in China. As a contemporary college student who shoulders the blueprint construction of the grand socialist cause, it's essential to learn how to do a good job. The brain and the hands are required to be used at the same time to face the contradictions bravely and solve problems skillfully.

\section{BEING HONEST AND TRUSTWORTHY, AND HOLDING THE CHARACTER OF "FAIRNESS, JUSTICE AND MORALITY"}

Zhou Enlai once said, "The wisest man in the world is the most honest man, because only an honest man can stand the test of facts and history. Honesty is not only the noble quality of truth in life beliefs, but also a lofty moral realm. Only a short while ago, "the moral degeneration of the world is getting worse day by day and human hearts are not what they were in the old days", and "honesty" has become a derogatory term. Under the influence of the tide of the market economy, it is not uncommon for honest people to suffer losses."Honesty" has become an endorsement word for "loss". Honest people are not mediocrity, incompetent people, but those people who dare to speak honestly, dare to do honest things and they are selfdisciplined, frank and fair and decent. Honesty is not only the foundation of establishing oneself in society, achieving glory by writing and setting up the conduct, but also the cornerstone of moulding personality charm. As a contemporary young college student, it's necessary to be honest and trustworthy and hold the character of "fairness, justice and morality". The first thing is to be an honest man. The process of university learning is a critical period for university students to shape their personality charisma and improve their knowledge and skills. In this process, young college students must learn to be honest, be self-disciplined and be frank. It's important for them to have affections for teachers, have genuine feelings for their classmates, and be passionate about learning. Only in this way can they gain the trust of our teachers and win the support of our classmates, so that a relaxed and pleasant learning environment will be created, which is helpful for their healthy growth. The second is to tell the truth. That is to say, words and deeds should be self-restricted and the rules shall not be broken easily. It is necessary to suit the action to the word, act with proper method and match words to deeds. It's forbidden to be the people of "two sides", who are characterized with complying in appearance but opposing in heart. In the end, it will be eliminated by the social and historical process if someone conceals the true state of affairs from above and below oneself. As Henie said, "life is impossible to make brilliant flowers out of lies. The ancients said "He whom riches and honors cannot corrupt nor poverty and obscurity divert, whom neither threats nor violence can bend\& he it is that I call a great man". Wen Tianxiang of ancient times and Jiao Yulu of modern times, are all able to achieve eternal fame because of their unswerving spirits. In the process of the dream of building a powerful country, the contemporary young college students must keep their tenacity, down to earth while aiming high. Only by holding a road unswervingly, can the dream of great rejuvenation of the Chinese nation can be realized and a powerful socialist country can be truly built.

\section{CONCLUSION}

All in all, the bear spirits practice of contemporary young college students not only means inheriting the fine historical traditions of the Communist Party of China, but also means highlighting the new demands of the times; it is the spiritual support and work style guarantee of carrying on the history, carrying forward the cause and forging ahead into the future, shouldering the responsibility and successfully carrying out the 
mission and also the spirit regeneration of the contemporary young college students to pursue excellence, be brave to live up to their responsibilities and be good at acting, in order to write a new chapter in the magnificent Chinese dream process.

\section{REFERENCES}

[1] The Textbook of A Series of Important Speeches of General Secretary $\mathrm{Xi}$ Jinping[M].The Tibet People's Publishing House,Publicity Department of the Communist Party of China, 2014. 习近平总书记系 列重要讲话读本 $[\mathrm{M}]$. 西藏人民出版社, 中央宣传部, 2014.

[2] The Outstanding Contribution of Liu Shaoqi to the Chinese Literature and Arts Cause-Comment on Two Speeches of Liu Shaoqi on Literary and Art Work in 1956[J].Liu Peng.Journal of Yuxi Normal University. 2003(02) 刘少奇对新中国文艺事业的卓越贡献一一评 1956 年刘少奇关于文艺工作的两次讲话[J].刘鹏.玉溪师范学院学报. 2003(02)

[3] Analysis of the Reasons and Control Strategies for the Loss of Academic Morality in Colleges and Universities[J].Hao Junjie.Heilongjiang Researches on Higher Education.2011 (01) 高校学 术道德失范的原因透析及防治策略[J].郝俊杰.黑龙江高教研究.2011 (01)

[4] Strictly Discipline Oneself and Be APolitically Savvy Person- Exchange Speech at the Second Topic Study Seminar of the "Three Stricts and Three Honests"Special Education of the Leading Party Group of the Standing Committee of Municipal People's Congress[J].Wu Hanmin.Monthly of Shanghai Municipal People's Congress.2015(12) 严以律己,做政治上的明白人一一在市人大常委 会党组 “三严三实” 专题教育第二专题学习研讨会上的交流发言 [J]. 吴汉民.上海人大月刊.2015(12) 